\title{
EchoGéo
}

\section{Restructuring of Rural Governance in a Rapidly Growing Resource Town: The Case of Kitimat, BC, Canada}

Laura Ryser, Greg Halseth and Sean Markey

\section{(2) OpenEdition \\ Journals}

Electronic version

URL: https://journals.openedition.org/echogeo/15218

DOI: 10.4000/echogeo.15218

ISSN: 1963-1197

Publisher

Pôle de recherche pour l'organisation et la diffusion de l'information géographique (CNRS UMR 8586)

Electronic reference

Laura Ryser, Greg Halseth and Sean Markey, "Restructuring of Rural Governance in a Rapidly Growing Resource Town: The Case of Kitimat, BC, Canada", EchoGéo [Online], 43 | 2018, Online since 22 March 2018, connection on 23 August 2021. URL: http://journals.openedition.org/echogeo/15218 ; DOl: https://doi.org/10.4000/echogeo.15218

This text was automatically generated on 23 August 2021.

EchoGéo est mis à disposition selon les termes de la licence Creative Commons Attribution - Pas d'Utilisation Commerciale - Pas de Modification 4.0 International (CC BY-NC-ND) 


\section{Restructuring of Rural Governance in a Rapidly Growing Resource Town: The Case of Kitimat, BC, Canada}

Laura Ryser, Greg Halseth and Sean Markey

\section{Introduction}

1 Many resource-dependent regions have encountered significant industrial investment in the past decade. The scale of these investments has the potential to transform these communities. In Canada, the context of resource-dependent community development, however, is very different now than it was when industrial resource development expanded in the 1950s and 1960s. In the immediate post-war period, a high demand for resources and limited competition prompted a long boom that was led by significant state investments to expand resource-producing regions (Halseth, 2017). Investments to develop new highways, instant towns, facilities, and services were put in place, all with the goal to improve the quality-of-life needed to attract a workforce to these remote regions (Scarpa, 2013; Sullivan et al., 2014). Following the recession of the early 1980s, senior governments and industries reduced their role in resource-dependent regions. Rising costs, lengthier approval processes, and a desire to reduce government expenditures all supported this policy transition (McDonald et al., 2012). At the same time, resource-based economies have been transformed by industry's pursuit of automation, improvements in transportation and communication, global competition, and more fluid flows of capital and labour (Tonts, 2010). Communities now receive fewer job benefits, and the removal of supportive state policies has left these places more exposed to the vulnerabilities of resource commodity markets.

2 Since the 1980s, neoliberal public policies have also left resource-based communities without new investments in the infrastructure and programs needed to better position 
these places ahead of periods of rapid growth. Even as this political economy evolves, past neoliberal policy responses continue to restrict supports while also failing to offer a comprehensive strategy to guide rapidly growing communities. This has prompted local governments to pursue more entrepreneurial and innovative pathways to strengthen and diversify their economy. The abandonment of top-down policy levers has also prompted community groups to pursue a greater voice in decision-making by opening up public participation in new local governance arrangements (Markey et al., 2012). As the presence and capacity of senior levels of government to respond to rapid change has waned, these new arrangements are seeking to implement processes and mechanisms that widen the scope of participation and ensure that local resources and capacities are deployed in the most timely and effective way to address the pressures and opportunities emerging in these places. These changes are characterized in the literature as a shift from traditional top-down government to co-constructed governance (Cheshire et al., 2014; Shucksmith, 2010).

3 This paper investigates how local governments, in growing rural resource regions, respond to change in a dynamic neoliberal environment. Drawing upon the case study of Kitimat, British Columbia (BC), Canada, we explore how one small town is coping with rapid change in the face of three conceptual shifts that are reshaping resourcedependent communities. These include 1) broader shifts in the neoliberal policy environment, 2) the shift from managerialism to entrepreneurialism in local government, and 3) the shift from government to governance in local planning processes.

\section{Kitimat, British Columbia, Canada}

4 Kitimat is located on the northwest coast of $\mathrm{BC}$ (Illustration 1) in the traditional territory of the Haisla First Nation. It is approximately $62 \mathrm{~km}$ south of the regional centre of Terrace. By air, it is $650 \mathrm{~km}$ north of Vancouver. With a long history of industrial investment, Kitimat's development is rooted in the 1950s when the Aluminum Company of Canada (Alcan) selected the area as the site for its new aluminum smelter. Over the next decades, the industrial base diversified through investments in Eurocan's pulp and paper mill (1967) and Ocelot's methanol and ammonia production (1980s).

5 The period since the 1980s, however, has been marked by rapid change and decline. Global competition and restructuring pressures prompted the closures of both Methanex (2005) (formerly Ocelot) and Eurocan (2010) - a direct loss of 662 jobs. Industrial investments that Alcan set in place were also aging and losing their competitive edge in the global marketplace.

6 As a planned 'instant town', Kitimat was designed to accommodate an industrial population of over 50,000 people. However, its actual population has never exceeded an official count of more than 13,000 people. In 1961, shortly after construction of the Alcan smelter, the census population was 8,217. Once the Eurocan pulp mill was completed, and through the 1970s, 1980s, and 1990s, Kitimat's population averaged between 11,000 and 12,000 people. Between 2001 and 2011, however, out-migration in response to job losses reduced the local population to 8,335. In addition to absolute population loss, and following the processes of 'resource frontier aging' (Hanlon and Halseth, 2005), the median age of the community has increased to now over 44 years. 
7 In 2010, Rio Tinto Alcan (RTA) announced that it would modernize its aluminum smelter at a cost of $\$ 4.8$ billion in order to increase production by more than $48 \%$ (Rio Tinto Alcan, 2011). As construction began in 2011, it required roughly 3,500 construction workers, reaching peak construction in 2014, and would lead to approximately 1,000 permanent jobs in the new smelter. This project, however, is just one component of a new era of industrial investment proposed for the area. As a sheltered port on the north coast of $\mathrm{BC}$, with its shorter sailing times to Asian markets compared to southern ports in North America, Kitimat became the designated port for at least two proposed oil / bitumen / condensate pipeline projects. Additional industrial investment also developed as part of a global 'rush' in the early to mid-2010s to build liquefied natural gas (LNG) industries. It soon became the proposed port of choice for at least four large LNG projects (Petroleum Human Resources Council of Canada, 2013). For the small town of Kitimat, proposed investments of all of these industrial projects totaled more than $\$ 73$ billion.

Illustration 1 - Kitimat-Stikine Regional District

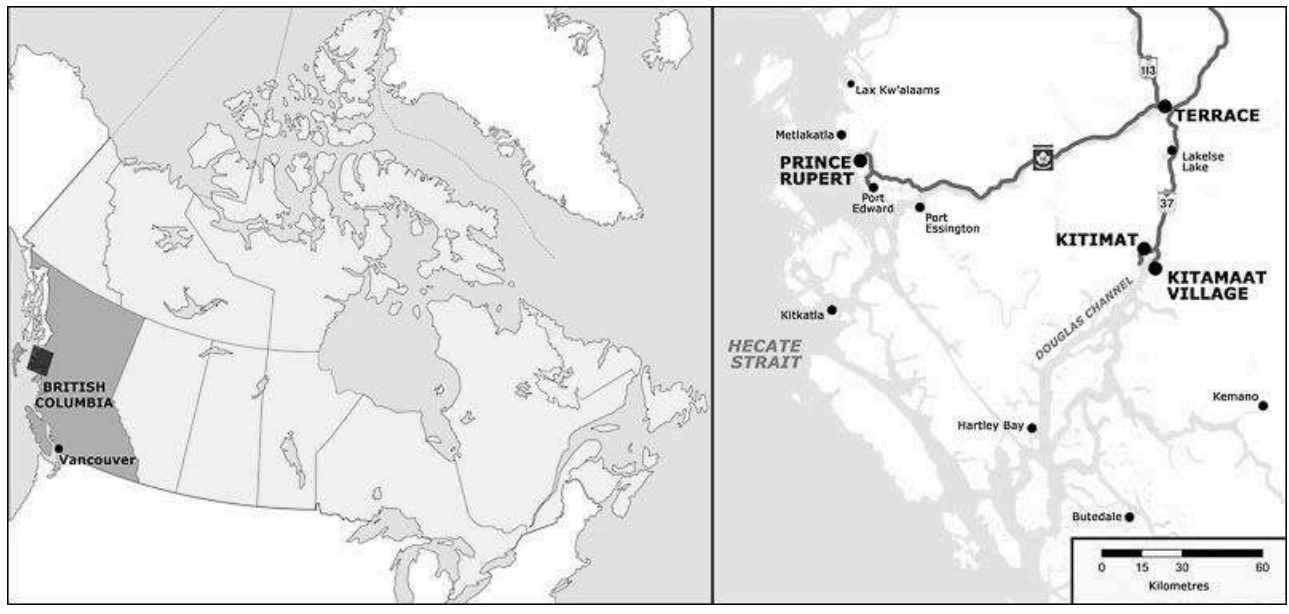

Map credit: Kyle Kusch.

When major industrial investments come to small communities, the local economic and social impacts can be significant and transformative but also incredibly challenging as community stakeholders work to secure the resources and supports needed to mitigate the pressures associated with rapid growth, as well as to maximize the legacy from these large-scale industrial developments. Since 2012, our research team has conducted five field research visits to Kitimat to better understand shifts in rural governance structures as stakeholders coped with rapid change. During each visit, we conducted between 37 and 45 interviews, for a total of 204 interviews over four years. Interview participants included residents, service providers, local government leaders, industry representatives, business leaders, and members of community groups based on a stratified purposeful sampling approach (Suri, 2011). The interviews tracked changes in the community from a variety of perspectives: as a result of large-scale industrial development projects; with community engagement and capacity; in collaborative working and governance relationships; and any new strategic actions and investments. During each interview, comments were recorded in order to generate a detailed file that could be sent and reviewed by each participant. The research team conducted 
latent and manifest content analysis (Krippendorff and Bock, 2009) to identify, code, and categorize patterns and themes that emerged from the data.

\section{Findings}

9 Our findings link to three conceptual shifts that are shaping the capacity and renewal of Kitimat. These conceptual shifts include the neoliberal public policy environment, the shift from local government managerialism to entrepreneurialism, and the shift from government to governance in local planning and decision-making, all of which occur in a reflexive relationship.

\section{Neoliberal Public Policy Shift}

10 Neoliberalism is grounded in both fiscal and ideological pressures to reduce government expenditures and increase the role of non-profit and private sector contractors in the delivery of public services (Osborne and McLaughlin, 2002). In its place, state intervention has assumed a secondary role of seeking to facilitate or manage development and service delivery through various community and regional programs, or simply to rely on (de)regulation and market forces to determine the level, format, and location of services and programs (Klein et al., 2009; Markey et al., 2007). Reinvestments in resource-industry communities also became more limited in the post-1980s as successive senior governments chose instead to run down previous assets. The reductions in spending and investments limited support for community renewal and transformation processes.

11 At the local level, responsibilities for coping with change have historically fallen to the local government. As is common for small towns in BC, the local government council and staff in Kitimat is relatively small. The six local councilors and the mayor are each elected directly by the population living within the town boundaries. In 2017, a staff complement of approximately 35 is distributed across nine departments including general administration, finance, economic development, leisure services, building inspections, engineering, planning, fire department, and public works. Police and the ambulance services are provided on a contract basis by the Royal Canadian Mounted Police and the $\mathrm{BC}$ ambulance service respectively. The size and structure of the local government has remained relatively unchanged for decades. The role and functions of all local government in British Columbia is directly legislated by the provincial government ${ }^{1}$ (Bish and Clemens, 2008). One of the continuing challenges for small towns is the failure of the provincial government to revise the jurisdictional authority and financial powers of local governments commensurate with the needs being generated by social, economic, and demographic restructuring at the local level (Halseth and Ryser, 2016).

12 As small local governments have been asked to do more around community and economic development, these same governments have been constrained by outdated structures of fiscal, policy power, and authority for supporting rural renewal (Halseth et al., 2017). In the case of Kitimat, the provincial government even argued that any efforts by the local government to raise industry tax rates to pay for the pressures being put onto the community's social and physical infrastructures during an economic boom could jeopardize proposed LNG projects (Lee, 2014). This prompted the Province's 
warning about the potential to apply their port taxation policy - which would have introduced a property tax cap - leaving small local governments like Kitimat to fear provincial intervention to set local tax rates.

13 During large/mega project construction periods, local economic and social stakeholders can be challenged to secure the resources and supports needed to mitigate the pressures associated with rapid growth. Prior to the new period of rapid growth in Kitimat, cuts were made to community services during previous periods of economic recession. Once community groups lost provincial funding, it was difficult to re-establish since provincial and federal government contracts to non-profits were not adjusted to respond to rapid growth. Despite pressures created by the $\$ 4.6$ billion Kitimat Modernization Project (KMP) and site preparations for multiple LNG/Oil/ Bitumen projects, the provincial government was reticent to invest new resources in social housing, for example, until final investment decisions were made by LNG proponents. As the provincial minister responsible for both natural resource development and social housing, Minister Rich Coleman preferred to let the market react to local housing pressures during the KMP (Hoekstra, 2014). As one stakeholders noted,

"The local government brought forward a bylaw that would add a type of density bonusing scheme for camps. This was a council initiative to create a level playing field. Why wouldn't [the large LNG proponents like] Shell / Chevron pay into the affordable housing fund if we were asking [the small worker accommodation companies such as] PTI or Crossroads to do so? This got the attention of provincial ministries. Suddenly, there was money for the action plan as long as we postponed passing this bylaw. So for a couple of years, the message was "no there's no problem with housing in Kitimat and if there is a problem, we'll address them when the LNG plants are built because then there'll be money to do something about it." Despite our messaging that we're impacted now by industry whether LNG is built or not, I think that when we were trying to address it ourselves to raise money to do something about it and it was impacting industry, industry went to the province and the province came to us.

" (Kitimat Participant \#8, 2014)

As senior levels of government increasingly downloaded their role to deliver services, the local government, community groups, and the private sector found it had to step in to secure urgently needed housing supports, training, and infrastructure in other ways. For example, the stability of community social services has been supported by the local government's initiative to establish a $\$ 200,000$ emergency fund for social services, despite the fact that these services fall under provincial government jurisdiction. By 2014, Kitimat had the third lowest vacancy rate (1.3\%) and second highest rental rates in the province (Halseth and Ryser, 2016). With an increase in homelessness and displaced residents in the community, the Child Development Centre (CDC) and the local government were only able to obtain a three-month federal government grant from the Homeless Partnering Strategy to support a temporary housing support worker to assist displaced residents. The local government felt it had a responsibility to act, which caused them to allocate funding to hire two housing support workers until additional funds could be secured. Local government staff also worked with community service providers, church volunteers, and BC Housing to develop an emergency coldweather response shelter in 2014. The shelter was located in the local fire hall and was initially operated by local government staff who volunteered during the evenings and weekends. Some stakeholders we spoke with, however, felt that the provincial government had not been proactive enough to manage housing pressures during the early stages of rapid growth. 
Much of the physical infrastructure in Kitimat was put in place during the construction of the townsite in the 1950s. Despite massive development pressures in Kitimat, there was no reinvestment to upgrade or replace that infrastructure. For example, the only bridge that connected the main part of town with the industrial area has needed replacement for many years. Equipment and construction components had to be dismantled and then transported over a bridge that was aging and had limited load capacity. Intermittent repairs have been done to the bridge throughout this period of rapid growth, with more significant senior government investments to replace the bridge being put off until Final Investment Decisions (FIDs) by the large LNG projects were made. As one stakeholder explained,

"The traffic on the roads...the bridge. I mean how many times has the bridge acted as a bottleneck over the last four years. How many years has the District of Kitimat been pounding on everybody's door to upgrade that bridge? Probably we'll be upgrading during the time of the next boom. We still, from a liability point of view, we still have an old bridge that if it went down right now, you and I would take two hours to get to the same place that we would normally get to in four minutes. Billions of dollars' worth of industry would be isolated on the other side." (Kitimat Participant \#15, 2015)

The neoliberal policy shifts that continue to be pursued by both provincial and federal governments have hampered their capacity to respond to the rapid changes that are taking place in Kitimat (Terrace Standard, 2014). As senior government ministries delayed their own investments, and as they have not mobilized adequate staff resources to have 'boots on the ground' to support service programs and to understand the local context (Halseth and Ryser, 2016), there has been no coherent senior government policy response to address the issues emerging in the new political economy.

\section{From Managerialism to Entrepreneurialism}

17 Part of the challenge for resource-industry towns has been to recognize the restructured industrial and neoliberal landscape and then transform their own planning and policy frameworks to reflect this new reality. As senior governments and industry have generally become less engaged in community development, local governments have struggled to adopt a more entrepreneurial approach to their operations. Hayter (2000, p. 288) describes this transition from 'managerialism' to one where resource-industry towns "had to contemplate becoming entrepreneurial and try to create ideas for development from within the community". This new reality for local development is driven by the neoliberal ethos of 'enabling' communities to devise their own economic and community development future. Within this policy ethos, however, senior governments have simultaneously reduced or eliminated many of the key supports that local governments need to realize new development strategies.

Local governments may themselves be challenged by a limited vision about how they can cope and evolve within the dynamics of restructuring. However, we also see examples where the regulatory framework limits potential innovative responses where local governments are seeking new solutions. For example, these communities have expressed interest in pursuing regional taxation schemes or community impact benefit agreements. The legislative framework in Canada, however, does not require these additional sources of revenue to be put in place. While revenue sharing agreements are needed to better position communities to respond to the opportunities and challenges 
associated with rapid growth, these pursuits may or may not be realized (Heisler and Markey, 2014). Communities need to be more aggressive, entrepreneurial, and innovative in order to capture jobs and economic development opportunities.

As industrial activity expanded in Kitimat, more contractor offices and retail businesses opened to diversify the economy. In this context, the local government, the Chamber of Commerce, and regional economic alliances all played a key role encouraging or attracting new business development with, for example, strategic investments in longterm planning through gap analyses and worker attraction surveys, organizing an energy conference, and by delivering procurement workshops to build the capacity of the local business community. These initiatives enhanced the local understanding of industry criteria used to evaluate procurement bids, including the financial and technical capacity, management structures, and past performance in order to determine the stability of the supplier. Through the Age-Friendly Committee and the Retire in Kitimat initiatives, local government leaders have also been working with community groups to diversify the economy and respond to the needs of an aging population.

The District of Kitimat also moved to support the transformation of aging commercial infrastructure by reducing property taxes for renovated commercial buildings. A new bylaw offers "a five-year tax exemption on the increase in assessed value to a maximum of $\$ 2,000,000$ " on retail buildings, warehouses, and accommodation businesses where at least $\$ 25,000$ or more in exterior improvements have been made (District of Kitimat, 2013).

21 The local government also seized the opportunity during this period of rapid growth to entice investments in older housing assets with more attention to new housing policies, such as strata conversion and secondary suite options. The new secondary suite incentive program, for example, provided a five year forgivable loan via a grant agreement with the local government for new secondary suites that were developed and introduced into the rental market. This policy included additional incentives for the provision of affordable housing through the development of secondary suites (Illustration 2). Kitimat also introduced a density bonusing scheme that would require construction camps to make contributions into an affordable housing fund. The contribution can be cash or in-kind in the amount of $\$ 500$ for each unit that becomes operational (District of Kitimat, 2014).

Illustration 2 - District of Kitimat Secondary Suite Incentive Program

\begin{tabular}{|l|l|}
\hline Type of Secondary Suite & Allowable Forgivable Loan \\
\hline Any suite & $\$ 2,500$ \\
\hline Level 1 affordable ( $\$ 645$ maximum for bachelor suite) & $\$ 5,000$ \\
\hline Level 2 affordable ( $\$ 575$ maximum for bachelor suite) & $\$ 7,500$ \\
\hline Any suite that is accessible for disabled & $\$ 2,500$ (bonus) \\
\hline
\end{tabular}

Source: District of Kitimat, n.d. 
With the completion of the KMP and uncertainty around the LNG projects, some investors were taking the opportunity to sell their rental units. Preparations for workforce accommodations to support LNG projects continued, however, as LNG Canada announced a ten-year lease agreement with a proposed new development in the downtown core. Located on old hospital property, the new facility will contain 150 condominium units, a hotel, commercial space, and a restaurant.

\section{From Government to Governance in Planning and Decision-making}

As the impacts of accelerating change in the global economy, new industrial investments, and neoliberal policy approaches converge on rural resource regions, community stakeholders have been forced to rethink the role of government and governance at the local level. Older government-oriented development models were defined by institutional structures that allow senior governments to directly deliver or fund programs and services in small communities. The neoliberal public policy transition meant that senior government policies increasingly sought to 'enable' bottom-up local representation and control over future development trajectories (Dufty-Jones and Wray, 2013).

The shift from government to governance has also been marked by an interest from community groups to seek greater involvement in decision-making to address local needs through new arrangements. This reflects calls for a wider inclusion of community and regional partners, as many social and economic issues are complex and beyond the mandate of any single local government or community group. A placeoriented approach to governance can be more effective compared to senior governments that have largely removed their community presence, and thus lost their capacity to understand and respond adequately (and in a timely manner) to changing conditions. Boosted by the cooperation of many local and regional stakeholders, a sense of local ownership generates quick decision-making and mobilization of resources that was not always possible under previous top-down regimes. Thus, a more focused attention to 'place' reveals a greater variety of assets and fosters an awareness that those assets are local and may be used for local purposes (Markey et al., 2012). In this context, new governance arrangements seek to understand collective capacities as roles and responsibilities for community development are redefined and redistributed. These new governance arrangements also fit with many tenets associated with new regionalism. With the displacement of senior government engagement in rural and resource-based regions, new regionalism has been tracking the reconfiguration of governance as regions experiment with different institutional structures and relationships in an attempt to compensate for government withdrawal and innovate to establish better local participation, competitive advantage, and economies of scale (Scott, 2004; Shucksmith, 2010; Uyarra, 2010). The effectiveness of these new governance arrangements, however, can be impacted by varied participation, unequal power relationships, and conflict across stakeholders (Peterson et al., 2010; Zirul et al., 2015). Halseth et al. (2010) also add that new governance regimes will only be effective if accompanied by sufficient resources and allowed time to develop mature leadership, trust, and structures capable of sustaining momentum.

In Kitimat, the economic recession of 2008, the closure of Eurocan, and the rapid growth associated with the KMP and pipeline announcements led to the development 
of new governance arrangements to strengthen collaborative responses to socioeconomic pressure and change. The community started two 'dialogue' groups. A Tier One dialogue group focused on economic opportunities and challenges, while a Tier Two dialogue group focused on social and community matters. Membership in the Tier Two dialogue group included public and voluntary/non-profit service providers (Illustration 3). While most groups were from Kitimat, several groups from the neighbouring community of Terrace, which provide services in Kitimat, attended as well. The relationship to Terrace is important. This regional centre is only about 45 minutes by car and has grown its retail and service functions over the past two decades to the detriment of small surrounding communities. Many provincial service staff have been relocated to Terrace, and many of the 'local' services in Kitimat are now in fact delivered out of Terrace.

Early planning meetings of the Tier Two dialogue group included presentations by the local Chamber of Commerce and Alcan (now Rio Tinto). These presentations helped to set the stage with respect to the scope, scale, and timing of potential effects from the smelter modernization project as well as some smaller and related proposed projects. To support this two-tier approach, those at the planning meeting endorsed using the existing 'Interagency Committee' as a working group to deal with the impending changes. The Interagency Committee was a routine informal gathering of social service and community groups where people shared information about their activities. These meetings were also routinely attended by industry representatives and contractors such as Rio Tinto, Bechtel, and LNG Canada. Meeting monthly at the local Child Development Center office, the group acted as an early warning system with respect to some of the more subtle socio-economic changes in the community.

Illustration 3 - Kitimat/Terrace Tier 2 Impact Dialogue Group Membership

\begin{tabular}{|l|l|}
\hline Adult Literacy & Kitimat Victim Services \\
\hline Adult Mental Health & Make Children First (Terrace) \\
\hline Alcan & Ministry of Children and Family Development \\
\hline Axis Family Resources & Ministry of Employment and Income Assistance \\
\hline BC Schizophrenia Society & Northwest Community College \\
\hline Child Care Resource and Referral & Northwest Regional Hospital \\
\hline Coast Mountains School District \#82 & Public Library \\
\hline Community Development Institute, UNBC & RCMP \\
\hline District of Kitimat - Council & Robin Austin, MLA \\
\hline District of Kitimat - Recreation & School Trustee \\
\hline Family Justice Center & Skeena Diversity Committee (Terrace) \\
\hline Kitamaat Village Council & Tamitik Status of Women \\
\hline
\end{tabular}




\begin{tabular}{|l|l|}
\hline Kitimat Chamber of Commerce & Terrace Child Development Center \\
\hline Kitimat Child Development Center & UNBC - Terrace Campus \\
\hline Kitimat Community Services & \\
\hline
\end{tabular}

Source: Kitimat Child Development Center, personal communication, 2014.

27 Through the Interagency Committee, other collaborative structures emerged to address specific topics such as youth programs, housing, economic development, poverty, physical and mental health, and seniors' needs. Through dialogue, members of the Interagency Committee were able to form various shared decision-making partnerships that have included the Housing Committee, the Violence Against Women in Relationships Coordination Committee, the Community Response Network, the Early Years Initiative, Integrated Case Management teams, and others. Through these collaborative structures, service agencies improved communication and access to information; improved their understanding of protocols and procedures; improved access to a broader range of resources and expertise; shared human resources to deliver joint events; achieved greater efficiency through joint service agreements and new protocols; and determined who could best address local gaps.

Despite the innovative nature of these collaborative initiatives, they also experienced challenges. In some cases, cooperation continued to be restricted, sporadic, or scattered. There were challenges moving beyond sharing information towards more action-oriented activities. Collaboration was also impeded by a lack of time, commitment, different expectations and scales of operation, different mandates and regulations, conflicting approaches to partnership management and activities, an unwillingness to share resources, previous conflicts, and limited understanding of protocols for engaging with industry or First Nations organizations. There was also a lack of funding, staff, and space to support collaboration at a local and regional level. All of these challenges underline the importance of pairing such significant industrial investments and pressures, with top-down supports needed to strengthen the development and viability of these local and regional governance structures.

\section{Conclusion}

Local governments in rural and small town resource-dependent regions now operate in a context that is very different from the post-war industrial era. Within our case study region, the expansion of large-scale industry investments in the 2010s have exposed the continued pursuit of neoliberal policy directives that have largely failed to mobilize constructive and timely responses to better position rural and resource-based communities in the new political economy. If local governments hope to fully capitalize on the opportunities afforded, they will need to deploy a two-pronged approach: 1) being more aggressive and purposeful in pursuing economic development that strategically capitalizes on the capacity and assets in the community; and 2) devising strategies to more effectively lobby senior governments for greater levels of (timely) support. Under the stress of rapid growth, our case study in Kitimat demonstrates how one community is addressing the deficiencies in neoliberal policy environments by 
pursuing broader governance arrangements and a more entrepreneurial approach to community development. By developing new governance structures, stakeholders have been able to address the inherent socio-economic pressures associated with rapid growth and initiate efforts to renew aging infrastructure.

Serious gaps, however, remain. Enthusiasm for new governance arrangements must be tempered, with an acknowledgement of the capacity limitations of rural and small town places. The combined resources of local actors may not be enough to maintain services and adapt on a continuous basis; local governance may become more symbolic of senior government abandonment than local empowerment. The challenge moving forward is how to design, implement, and manage mechanisms of rural governance that will maximize the positive contributions of collaboration without burning out rural stakeholders or processes. These governance mechanisms must also better identify and understand their gaps and limitations, which may then become areas for senior government involvement and negotiation. New rural governance processes will require a nimbleness of response which older government processes could not, and did not have to, deliver. New governance arrangements continue to require top-down fiscal, program, and policy support. Even as senior governments remain very dependent on resource revenue streams, they are reluctant to change their neoliberal policy approaches to supporting rural regions. Both 'top-down' policy supports and 'bottom-up' community capacity are needed to transform and sustain complex rural economies.

\section{BIBLIOGRAPHY}

Bish R.L., Clemens E.G., 2008. Local Government in British Columbia. Richmond, BC: Union of BC Municipalities.

Cheshire L., Everingham J., Lawrence G., 2014. Governing the impacts of mining and the impacts of mining governance: Challenges for rural and regional local governments in Australia. Journal of Rural Studies, vol. 36, p. 330-339.

District of Kitimat, n.d. Secondary suites. Available on-line at: http://www.kitimat.ca/EN/main/ municipal/departments/community-planning-development/secondary-suites.html

District of Kitimat, 2013. Kitimat to reduce property tax for renovated commercial buildings. Available on-line at: http://www.kitimat.ca/EN/meta/news/archives/2013/kitimat-to-reduce-propertytax-for-renovated-commercial-buildings.html

District of Kitimat, 2014. Bylaw No. 1841: A bylaw to amend the Kitimat Municipal Code with respect to land uses permitted in the M1 manufacturing zone. Available on-line at: http://www.kitimat.ca/ assets/Municipal Hall/Public Notices/1841-14\%20M1\%20Manufacturing\%20Zone.pdf

Dufty-Jones R., Wray F., 2013. Planning regional development in Australia: Questions of mobility and borders. Australian Planner, vol. 50, n², p. 109-116. 
Halseth G, 2017. Transformation of resource towns and peripheries: Political economy perspectives. London and New York, Routledge, Taylor and Francis Group.

Halseth G., Markey S., Reimer B., Manson D., 2010. Space to place: Bridging the gap. In Halseth G., Markey S., Bruce D., The next rural economies: Constructing rural place in a global economy, Oxfordshire, UK, CABI International, p. 1-16.

Halseth G., Ryser L., 2016. Rapid change in small towns: When social capital collides with political/bureaucratic inertia. Community Development, vol. 47, $n^{\circ} 1$, p. 106-121.

Halseth G., Ryser L., Markey S., 2017. Contentious flexibility: Job losses in labour restructuring in Mackenzie, BC. In Halseth G., Transformation of resource towns and peripheries: Political economy perspectives, Oxford and New York, Routledge, p. 161-194.

Hanlon N., Halseth, G., 2005. The greying of resource communities in northern BC: implications for health care delivery in already under-serviced communities. Canadian Geographer, volume 9, $\mathrm{n}^{\circ} 1$, p. 1-24.

Hayter R., 2000. Flexible crossroads: The restructuring of British Columbia's forest economy. Vancouver, UBC Press.

Heisler K., Markey S., 2014. Navigating jurisdiction: Local and regional strategies to access economic benefits from mineral development. The Canadian Geographer, vol. 58, nº 4, p. 457-468.

Hoekstra G., 2014. BC boom already a bust for some; Heated economy drives up rental prices, drive out tenants who can't afford increases. The Vancouver Sun, October 27, p. A4.

Klein J., Fontan J., Tremblay D., 2009. Social entrepreneurs, local initiatives, and social economy: foundations for a socially inclusive strategy to fight poverty and exclusion. Canadian Journal of Regional Science, vol. 32, $\mathrm{n}^{\circ} 1$, p. 23-42.

Krippendorff K., Bock M., 2009. The content analysis reader. Thousand Oaks, Sage.

Lee J., 2014. Northern communities feel 'LNG effect'; Kitimat, Prince Rupert, Terrace feel strain as Rich Coleman warns on municipal tax rates. The Vancouver Sun, September 23, p. A1.

Markey S., Halseth G., Manson D., 2007. The (dis?)connected North: Persistent regionalism in northern British Columbia. Canadian Journal of Regional Science, vol. 30, $\mathrm{n}^{\circ}$ 1, p. 57-78.

Markey S., Halseth G., Manson D., 2012. Investing in place: economic renewal in northern British Columbia. Vancouver, BC, UBC Press.

McDonald P., Mayes R., Pini B., 2012. A spatially-oriented approach to the impact of the Raventhorpe nickel mine closure in remote Australia. Journal of Industrial Relations, vol. 54, $\mathrm{n}^{\circ} 1$, p. 22-40.

Osborne S., McLaughlin K., 2002. A new public management in context. In McLaughlin K., Osborne, S., Ferlie E., New public management: Current trends and future prospects, London, Routledge, p. 7-14.

Peterson A., Walker M., Maher M., Hoverman S., Eberhard R., 2010. New regionalism and planning for water quality improvement in the Great Barrier Reef, Australia. Geographical Research, vol. 48, n 3, p. 297-313.

Petroleum Human Resources Council of Canada, 2013. Labor demand outlook for BC's natural gas industry: Petroleum labor market information. Produced on behalf of the BC Natural Gas Workforce Strategy Committee. Retrieved from http://irrealty.ca/wp-content/uploads/ 2013/04/2013-02-21_final_bc_natural_gas_labour_demand_to_2020_report.pdf 
Rio Tinto Alcan, 2011. Rio Tinto to invest US\$2.7 billion to complete the modernisation of the Kitimat smelter. Retrieved from http://www.riotintoalcan.com/enG/media/media_releases_2199.asp

Scarpa S., 2013. New geographically differentiated configurations of social risks: Labour market policy developments in Sweden and Finland. In Harsløf I., Ulmestig R., Changing social risks and social policy responses in the Nordic welfare states, New York, Palgrave Macmillan, p. 220-245.

Scott M., 2004. Building institutional capacity in rural Northern Ireland: The role of partnership governance in the LEADER II programme. Journal of Rural Studies, vol. 20, n 1, p. 49-59.

Shucksmith M., 2010. Disintegrated rural development? Neo-endogenous rural development, planning and place-shaping in diffused power contexts. Sociologia Ruralis, vol. 50, n 1, p. 1-14.

Sullivan L., Ryser L., Halseth G., 2014. Recognizing change, recognizing rural: The new rural economy and towards a new model of rural service. The Journal of Rural and Community Development, vol. 9, $\mathrm{n}^{\circ}$ 4, p. 219-245.

Suri H., 2011. Purposeful sampling in qualitative research synthesis. Qualitative Research Journal, vol. 11, n², p. 63-75.

Terrace Standard., 2014. Aid coming to the region. May 14, p. 1.

Tonts M., 2010. Labour market dynamics in resource dependent regions: An examination of the Western Australian goldfields. Geographical Research, vol. 48, n² 2, p. 148-165.

Uyarra E., 2010. What is evolutionary about 'regional systems of innovation'? Implications for regional policy. Journal of Evolutionary Economics, vol. 20, n 1, p. 115-137.

Zirul C., Halseth G., Markey S., Ryser L., 2015. Struggling with new regionalism: Government trumps governance in Northern British Columbia, Canada. Journal of Rural and Community Development, vol. 10, $\mathrm{n}^{\circ}$ 2, p. 136-165.

\section{NOTES}

1. In Canada, the Canadian constitution recognizes only the federal and provincial levels of government. Local government is considered a responsibility of provincial governments. Municipalities come into existence through provincial legislation, and in $\mathrm{BC}$ they undertake tasks as delimited through the Municipal Charter. Local governments in this context operate under the legislative and jurisdictional framework that provincial governments set for it, and these frameworks can be quickly changed depending upon the desires of that provincial government.

\section{ABSTRACTS}

A new era of industrial development is unfolding in resource-dependent regions. In Canada, the local government context in these regions, however, is very different now than when industrial resource development expanded in the 1950s and 1960s. Drawing upon our case study in Kitimat, British Columbia, we highlight transformations associated with neoliberal policies that have affected rural governance. Neoliberal public policy shifts include wider changes where the state 
has become less involved in program and infrastructure investments in resource-dependent communities. Even as this political economy continues to evolve, past neoliberal policy responses continue to restrict local supports, while also failing to provide a comprehensive strategy to guide rapidly changing communities. In Kitimat, this has prompted a variety of responses emblematic of a shift from government to governance. The town has become more entrepreneurial and innovative to strengthen and diversify their economy. The abandonment of top-down policy levers has prompted community groups to pursue a greater voice in decisionmaking by opening up public participation in new planning and development processes. While new rural governance arrangements have provided positive and proactive contributions to emerging pressures, concerns persist about the long-term viability of these structures without a renewed vision, and accompanying policy, from senior governments to support rural communities and regions.

\section{INDEX}

Keywords: rural governance, neoliberalism, managerialism, boomtowns

Subjects: Sur le Champ - Sur le Terrain

\section{AUTHORS}

\section{LAURA RYSER}

Laura Ryser, ryser@unbc.ca, is Research Manager, Rural and Small Town Studies Program, University of Northern British Columbia, Canada.

\section{GREG HALSETH}

Greg Halseth, halseth@unbc.ca, is Professor, Rural and Small Town Studies, University of Northern British Columbia, Canada.

\section{SEAN MARKEY}

Sean Markey, spmarkey@sfu.ca, is Associate Professor, Resource and Environmental

Management, Simon Fraser University, Canada. 